\title{
Response of primary producers to nutrient enrichment in a shallow estuary
}

\author{
Eleanor H. Kinney ${ }^{1}$, Charles T. Roman ${ }^{2, *}$ \\ ${ }^{1}$ Graduate School of Oceanography, University of Rhode Island, Narragansett, Rhode Island 02882, USA \\ ${ }^{2}$ US Geological Survey, Biological Resources Division, Graduate School of Oceanography, University of Rhode Island, \\ Narragansett, Rhode Island 02882, USA
}

\begin{abstract}
Shallow coastal systems worldwide are exhibiting increased algal growth in response to nutrient enrichment. This study evaluates primary production patterns in an estuarine system (Bass Harbor Marsh, ME, USA) receiving low levels of anthropogenic nitrogen. Biomass, areal coverage and in situ oxygen production of green macroalgae, Ruppia maritima, and phytoplankton were measured over a growing season to determine net ecosystem production. Macroalgae and $R$. maritima exhibited seasonal biomass curves with early summer peaks; however, peak biomass of macroalgae [150 g dry weight (wt) $\mathrm{m}^{-2}$ ] was substantially greater than $R$. maritima $\left(33 \mathrm{~g}\right.$ dry wt $\left.\mathrm{m}^{-2}\right)$. Phytoplankton biomass, measured as chlorophyll $a$, was low $\left(<1 \mu \mathrm{g} \mathrm{l}^{-1}\right)$ early in the season and peaked $\left(11 \mu \mathrm{gl}^{-1}\right)$ following a mid-summer decline in macroalgal biomass, suggesting a competitive interaction with macroalgae. Instantaneous net production rates varied over the growing season for all 3 primary producers. $R$. maritima net production ranged from near zero to $3.7 \mathrm{mg} \mathrm{C} \mathrm{g}^{-1}$ dry wt $\mathrm{h}^{-1}$, with higher rates during summer and much of the seasonal variability explained by temperature. Macroalgal (0.88 to $5.0 \mathrm{mg} \mathrm{C}^{-1} \mathrm{dry}_{\mathrm{wt} \mathrm{h}}{ }^{-1}$ ) and phytoplankton $\left(0\right.$ to $\left.28 \mathrm{mg} \mathrm{C} \mathrm{m}^{-3} \mathrm{~h}^{-1}\right)$ net production did not exhibit any clear seasonal signal. Net primary production calculated on an areal basis demonstrated macroalgae's dominance in the lower basin of Bass Harbor Marsh, with peak summer rates $\left(400 \mathrm{mg} \mathrm{C} \mathrm{m}^{-2} \mathrm{~h}^{-1}\right)$ greatly exceeding maximum rates for both $R$. maritima (70 $\mathrm{mg} \mathrm{C} \mathrm{m}^{-2} \mathrm{~h}^{-1}$ ) and phytoplankton $\left(12 \mathrm{mg} \mathrm{C} \mathrm{m}^{-2} \mathrm{~h}^{-1}\right)$. When compared to other New England estuarine sites with short residence times, nutrient loading and peak green macroalgal biomass in Bass Harbor Marsh are relatively low; however, the strong dominance of opportunistic green macroalgae is a pattern that is characteristic of shallow coastal systems undergoing eutrophication.
\end{abstract}

KEY WORDS: Primary productivity - Eutrophication - Green macroalgae - Ruppia maritima Phytoplankton · Estuary $\cdot$ Maine, USA

\section{INTRODUCTION}

As coastal populations grow, eutrophication is becoming a major concern in response to anthropogenic nutrient loading. Studies in Australia (Lavery et al. 1991), Italy (Sfriso et al. 1987), and the United States (Ryther \& Dunstan 1971, Thorne-Miller et al. 1983, Valiela et al. 1992, Taylor et al. 1995) have investigated the consequences of nutrient inputs into different coastal systems. However, more information on ecosystem responses to nutrient enrichment, particularly in shallow coastal systems, is needed (Valiela et al.

- Addressee for correspondence.

E-mail: croman@gsosun1.gso.uri.edu
1992, Harlin 1995). Nixon (1995) has defined eutrophication as 'an increase in the rate of supply of organic matter to an ecosystem'. Eutrophication is often caused by an increase in inorganic nutrients. Elevated levels of organic matter can be supplied by external inputs or by primary producers within the system, and primary production time series measurements are one means of determining if a system is becoming eutrophied.

Coastal systems have exhibited varied patterns of response to nutrient inputs. While some have shown a phytoplankton-dominated response (Ryther \& Dunstan 1971), others appear to be dominated by macrophyte growth (Lee \& Olsen 1985, Valiela et al. 1992). In shallow eutrophied areas, such as Waquoit Bay (MA, USA) and the Peel-Harvey estuarine system (Australia), 
green macroalgae dominated the response and produced anoxic conditions at times of water column stratification (Lavery \& McComb 1991, D'Avanzo \& Kremer 1994). Blooms of phytoplankton in Venice Lagoon, Italy, were observed only after macroalgal decomposition had released nutrients into the water column (Sfriso et al. 1987). In nutrient-enriched enclosure experiments, macroalgal suppression of phytoplankton growth has been reported (Fong et al. 1993, Oviatt 1994). However in other enclosure experiments, nutrient additions have initiated phytoplankton blooms with subsequent declines in macrophyte biomass (Taylor et al. 1995). Factors responsible for triggering the different responses are not fully understood.

The objective of this study was to determine dominance in primary production of a marshestuarine system receiving low levels of nitrogen enrichment. Located on Mt. Desert Island, Maine, USA, Bass Harbor Marsh lies mostly within the confines of Acadia National Park. One of the freshwater brooks feeding the marsh system is carrying nitrogen leachate from a landfill and residential development near its headwaters. In this study, both biomass and instantaneous production of green macroalgae, Ruppia maritima, and phytoplankton were measured in order to estimate net system production. These estimates were used to determine the dominant primary producer on both a seasonal and annual basis. In addition, physical and chemical parameters were measured to evaluate factors controlling the growth and dominance of the different primary producers.

Anthropogenic nitrogen inputs have the potential to enhance primary production in nitrogen limited coastal systems (Howarth 1988, Oviatt et al. 1995). Bass Harbor Marsh offers the opportunity to study the interaction of 3 different primary producers in a system which may be responding to relatively low levels of nitrogen loading.

\section{MATERIALS AND METHODS}

Study area. Situated on the southwest coast of Mt. Desert Island, Maine, Bass Harbor Marsh encompasses 349 ha (Fig. 1). It is connected to the ocean through Bass Harbor, where a road causeway and a natural bedrock sill near the marsh mouth dampen the tidal range from $3 \mathrm{~m}$ in the harbor to $0.3 \mathrm{~m}$ within the marsh. Depths are shallow, generally less than $0.5 \mathrm{~m}$ at low tide. The system is well flushed, with a residence time of less than $3 \mathrm{~d}$. The main marsh creek meanders for

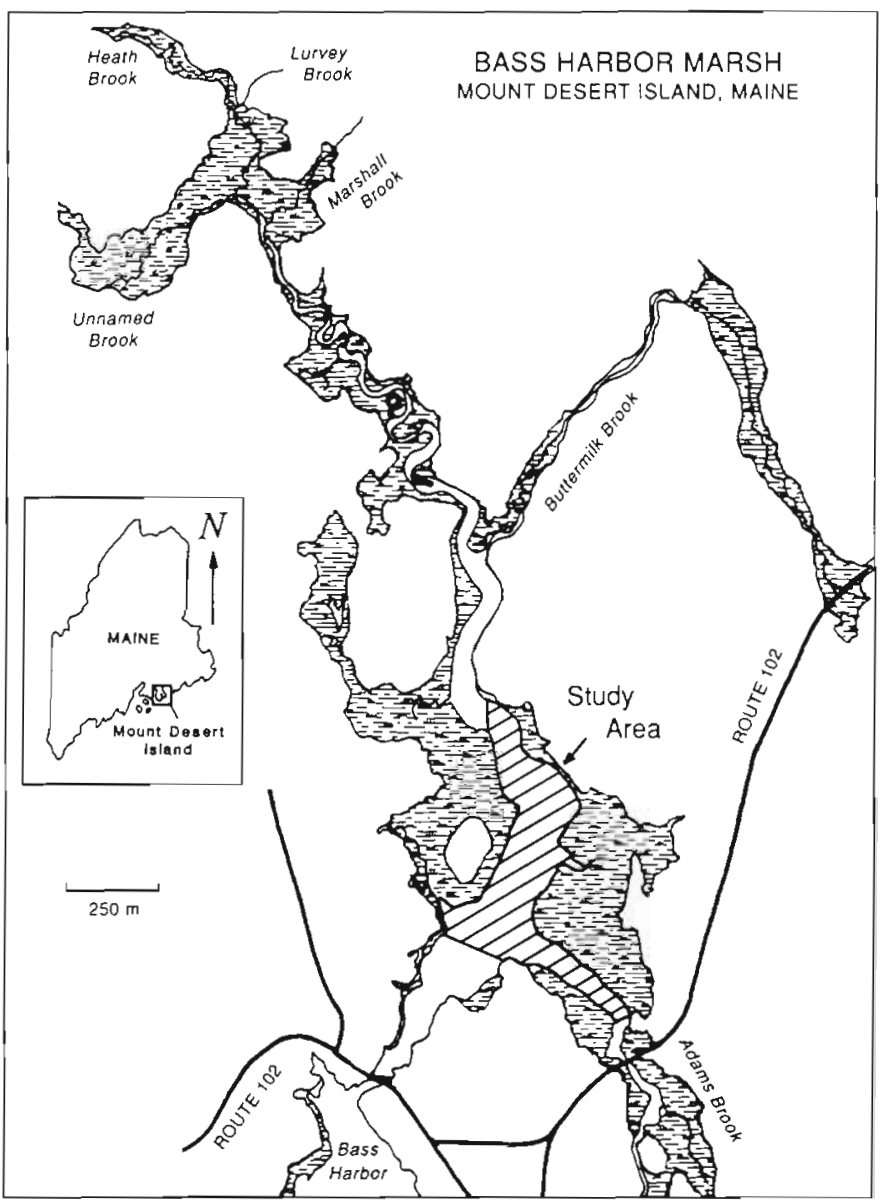

Fig. 1. Bass Harbor Marsh, located on Mt. Desert Island, off the Maine coast. Note the 20 ha study site in the lower marsh basin

approximately $3 \mathrm{~km}$ and is fed by 7 freshwater brooks. Salinities range from freshwater at the upstream tidal end to 32 parts per thousand (ppt) near the mouth. Total dissolved inorganic nitrogen loading from both the freshwater brooks and the ocean is $2.20 \mathrm{mmol}$ $\mathrm{m}^{-2} \mathrm{~d}^{-1}$ (Doering et al. 1995). The developed Marshall Brook drainage (landfill, residences) accounted for $74 \%$ of total freshwater nitrate-nitrite loading to Bass Harbor Marsh.

The marsh surface is dominated by short form Spartina alterniflora and other plants characteristic of saline to brackish-water systems. In the submerged portions of the lower marsh basin, Ruppia maritima, a few patches of Zostera marina, and green macroalgae species, principally Enteromorpha prolifera and $E$. flexuosa, all co-occur. E. intestinalis, Rhizoclonium riparium, as well as the the yellow-green alga Vaucheria sp. and the blue-green Microcoleus lyngbyaceus are also found.

All sampling was conducted in the lower marsh basin, a $200000 \mathrm{~m}^{2}$ area near the mouth where maxi- 
mum macroalgal growth occurred (Fig. 1). During the period from early April to late November, 1995, water temperatures in the lower basin ranged from 2.8 to $25.5^{\circ} \mathrm{C}$, and mid-day light extinction coefficients were variable due to wind and tidal scour in the shallow water column (Table 1).

Biomass sampling and mapping. Green macroalgal and Ruppia maritima biomass were sampled 11 times (April 4 and 25, May 25, June 6 and 20, July 6 and 25. August 15, September 14, October 18, and November 28) in 1995. Twenty $R$. maritima and 20 macroalgal quadrats were randomly collected along transects within the study area. A $0.05 \mathrm{~m}^{2}$ circular quadrat was inserted into the sediment and all belowground, aboveground and floating plant material harvested. Harvested material was washed on a $2 \mathrm{~mm}$ mesh sieve and all visible animals and non-target plant species removed. $R$. maritima leaves were separated from the rest of the plant. All plant samples were rinsed with deionized water and dried to constant weight at $60^{\circ} \mathrm{C}$. Dried samples were weighed and biomass calculated as grams dry weight ( $g$ dry wt) of plant tissue $\mathrm{m}^{-2}$ ( $g$ dry wt $\mathrm{m}^{-2}$ ). At the time of biomass sampling, areal plant coverage was mapped. The study area was surveyed by canoe, and the presence or absence of green macroalgae and $R$. maritima recorded on a base map derived from vertical aerial photographs (scale 1:9600). A range finder was used to help estimate distances within the $200000 \mathrm{~m}^{2}$ study area.

In situ productivity incubations. Instantaneous production of green macroalgae (Enteromorpha prolifera and E. flexuosal, Ruppia maritima and phytoplankton was measured within 24 h of each biomass survey with the exception of the April 4 sampling. That sample date occurred immediately after ice-out and prior to

Table 1. Physical parameters measured during the productivity experiments. Light data from mid-day light profiles are presented. Surface irradiance refers to measurements in air; bottom indicates measurements in water near $0.5 \mathrm{~m}$ depth. Ext. coeff.: extinction coefficient. All data are from 1995. ND: no data

\begin{tabular}{|c|c|c|c|c|c|}
\hline Date & $\begin{array}{l}\text { Water temp. } \\
\qquad\left({ }^{\circ} \mathrm{C}\right)\end{array}$ & $\begin{array}{l}\text { Salinity } \\
\text { (ppt) }\end{array}$ & $\begin{array}{c}\text { Irradiance } \\
\text { Surface }\end{array}$ & $\begin{array}{c}\left.\mu E m^{-2} s^{-1}\right) \\
\text { Bottom }\end{array}$ & $\begin{array}{c}\text { Ext. coeff. } \\
\left(\mathrm{m}^{-1}\right)\end{array}$ \\
\hline Apr 4 & 2.8 & 8 & ND & ND & ND \\
\hline Apr 25 & 6.0 & 18 & 1900 & 1120 & 1.4 \\
\hline May 25 & 21.5 & 18 & 1448 & 917 & 1.1 \\
\hline Jun 6 & 17.0 & 18 & 1085 & 289 & 2.2 \\
\hline Jun 20 & 20.5 & 24 & 1869 & 564 & 2.6 \\
\hline Jul 6 & 25.5 & 30 & 1781 & 856 & 1.4 \\
\hline Jul 25 & 22.0 & 20 & 682 & 245 & 1.7 \\
\hline Aug 15 & 21.0 & 31 & 531 & 233 & 1.4 \\
\hline Sep 14 & 19.0 & 32 & 303 & 153 & 1.4 \\
\hline Oct 18 & 13.0 & 20 & 1056 & 322 & 3.3 \\
\hline Nov 28 & 6.0 & 27 & 323 & 186 & 1.6 \\
\hline
\end{tabular}

the appearance of green macroalgae and $R$. maritima in the marsh; therefore only phytoplankton were incubated. Benthic microalgal production was not included in this study because a previous investigation found it to be a minor component of primary production in Bass Harbor Marsh (Farris 1996)

Five-liter chambers $(15 \mathrm{~cm}$ diameter, $30 \mathrm{~cm}$ height) were constructed of clear polycarbonate for the incubations. Three different treatments (phytoplankton, Ruppia maritima and macroalgae) were incubated, with each treatment containing 3 light chambers and 3 chambers made dark with opaque tape. In the $R$. maritima treatment, 0.1 to $0.6 \mathrm{~g}$ dry wt of leaf material were added to each chamber and, in the macroalgae treatment, 0.3 to $1.1 \mathrm{~g}$ dry wt of algae thalli. This amount of tissue was comparable to the range of macrophyte densities found in the field, except during peak macroalgal growth. More than $1.1 \mathrm{~g}$ dry wt of macroalgae per chamber was not used to avoid $\mathrm{CO}_{2}$ and nutrient deficiency during the incubations (Johnston 1969). Only the leaves of $R$. maritima (the photosynthetic portion of the plant) were placed in the chambers. Inclusion of whole plants may have resulted in internal oxygen utilization (Thursby 1984a), making it difficult to use change in dissolved oxygen as a means of measuring oxygen production.

Initial oxygen samples were collected for each treatment and fixed immediately using the azide oxygen method (American Public Health Association 1980). Incubations were conducted during mid-day 109:30 to 15:30 h), and the chambers were suspended $25 \mathrm{~cm}$ below the surface with clear plastic buoys. The $30 \mathrm{~cm}$ high chambers encompassed over half the mean $0.5 \mathrm{~m}$ water column. Chambers with only ambient water were incubated 5 to $6 \mathrm{~h}$. The water was unfiltered, including the entire water-column community; however, because primary producers were the focus of this study, this treatment is referred to as the phytoplankton treatment. Ruppia maritima was incubated 3 to $6 \mathrm{~h}$, and macroalgae 2 to $5 \mathrm{~h}$, with shorter times used during the warm summer months. The macrophyte tissue used was sparsely epiphytized, and thus the incubations represent a community response. The chambers were shaken every 30 to $60 \mathrm{~min}$ to avoid stratification and the depletion of nutrients in the water immediately surrounding the plants (Littler 1979). During the incubations, 2 to 3 light profiles $\left(\mu \mathrm{E} \mathrm{m}^{-2} \mathrm{~s}^{-1}\right)$ were taken adjacent to the chambers with a Li-Cor LI-1000 light meter (LI-192SA and LI-190SA radiation sensors). Ambient water temperature and salinity were measured with a mercury thermometer and refractometer, respectively. 
Immediately following the incubation, four $60 \mathrm{ml}$ biological oxygen demand bottles were filled from each chamber and fixed. Plant material was then collected from the chambers, rinsed with deionized water, and dried to constant weight at $60^{\circ} \mathrm{C}$. Dried plant tissue was ground to a fine powder and stored frozen for later organic carbon and nitrogen analysis on a Carlo-Erba NA 5000 CHN analyzer.

Initial chlorophyll a samples collected for each treatment were filtered the day of collection through Whatman GF/F glass fiber filters, preserved with magnesium carbonate solution, and stored frozen for less than 1 mo before being analyzed. Chlorophyll a concentrations were determined using acetone extraction and fluorometric analysis on a Turner design series 10 Fluorometer (Strickland \& Parsons 1972). Initial nutrient samples were filtered the day of collection, preserved with chloroform and frozen until the time of analysis. Concentrations of nitrite+nitrate, ammonium and phosphate were determined colorimetrically on a Technicon II autoanalyzer (Strickland \& Parsons 1972).

Productivity calculations. Oxygen production and respiration were calculated as $\mathrm{mg} \mathrm{O}_{2} \mathrm{~g}^{-1}$ dry wt $\mathrm{h}^{-1}$ for the macrophytes and as $\mathrm{g} \mathrm{O}_{2} \mathrm{~m}^{-3} \mathrm{~h}^{-1}$ for phytoplankton. To facilitate comparison with the literature, oxygen production was converted to carbon production using photosynthetic quotients of 1.2 (Oviatt et al. 1986, Valiela 1995), 1.25 (Murray \& Wetzel 1987) and 1.2 (Arnold \& Murray 1980, Peckol \& Rivers 1996) for phytoplankton, Ruppia maritima, and macroalgae, respectively. For the macrophytes, carbon production on an areal basis was determined by combining the incubation results ( $\mathrm{mg} \mathrm{C} \mathrm{g}^{-1}$ dry wt $\mathrm{h}^{-1}$ ) with the biomass results ( $g$ dry wt $\mathrm{m}^{-2}$ ) to yield $\mathrm{mg} \mathrm{C} \mathrm{m} \mathrm{m}^{-2} \mathrm{~h}^{-1}$. $R$. maritima leaf biomass was used in these calculations because only the leaves were incubated. System production for the study area was calculated using the mapping results $\left(\mathrm{m}^{2}\right.$ of macrophyte cover/system) and was expressed as mg $C$ system $^{-1} \mathrm{~h}^{-1}$. Phytoplankton net production was also calculated on an areal and system-wide basis using depth profiles to determine water volume within the study area. Hourly net production rates were converted to daily rates using Vollenweider's (1965) methods. For each incubation day, day length (sunrise to sunset) was divided into 5 equal periods, with each period having a different percentage of total daily production. Hourly incubation rates were then converted to daily (daylight, not $24 \mathrm{~h}$ ) rates based on the duration and timing of the incubation. Although developed for phytoplankton, this calculation was applied to macroalgae and $R$. maritima as well since phytoplankton, macroalgae and seagrass have a similar relationship between light and photosynthetic rates (Valiela 1995). To estimate net annual daylight production, daily rates were then plotted against time and the area under the curve integrated.

\section{RESULTS AND DISCUSSION}

\section{Macrophyte biomass}

Ruppia maritima and macroalgae exhibited strong seasonal trends in biomass during 1995. Macroalgal biomass increased from zero in April to an early summer peak of $150 \mathrm{~g} \mathrm{dry} \mathrm{wt} \mathrm{m}^{-2}$, followed by a sharp decline during July and August (Fig. 2). In fall, macroalgal biomass maintained a density of about $15 \mathrm{~g}$ dry wt $\mathrm{m}^{-2}$. $R$. maritima was similar to macroalgae in seasonality, but it had much lower biomass. $R$. maritima biomass increased from zero in early April to a July maximum of $33 \mathrm{~g}$ dry wt $\mathrm{m}^{-2}$, followed by a gradual decline through the remainder of the growing season (Fig. 2).

Biomass of macroalgae and Ruppia maritima in Bass Harbor Marsh falls within the range of values reported in other coastal areas (Table 2). While peak $R$. maritima biomass seen in this study is comparable to those observed in Rhode Island (USA) coastal ponds and in Chesapeake Bay (VA, USA), it is an order of magnitude lower than peak values measured in the previous 1991 Bass Harbor Marsh study (Doering et al. 1995). However, in the 1991 study, R. maritima was collected further upstream, and differences in hydrology, nutrient dynamics, and other environmental factors may be driving the different biomass levels. Furthermore the 1991 site was free of macroalgae.

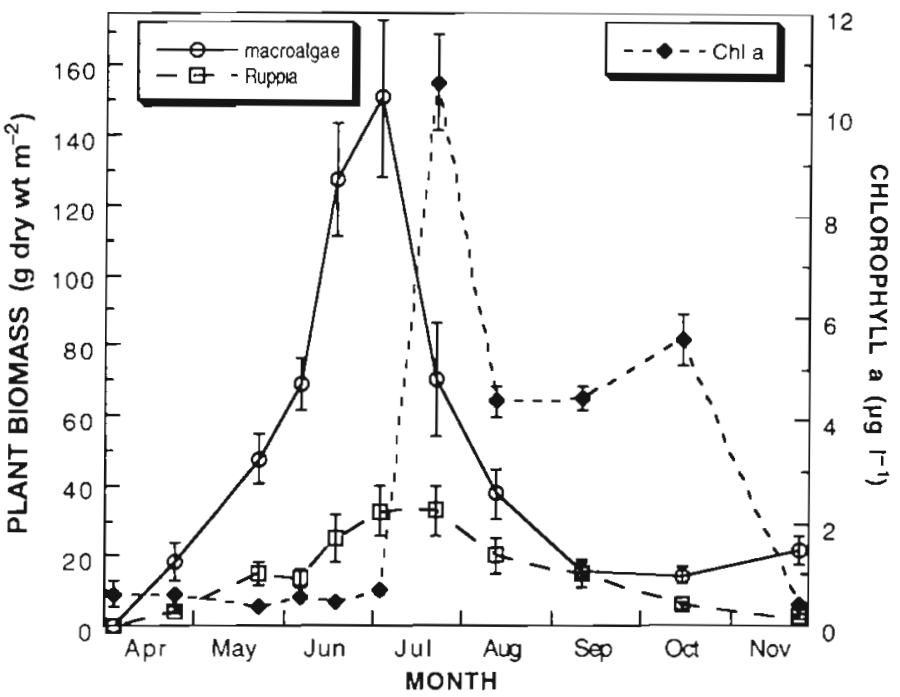

Fig. 2. Macroalgae, Ruppia maritima, and phytoplankton (chlorophyll a). Biomass measured over the growing season. Mean \pm standard error $(\mathrm{n}=20$ for macroalgae and $R$. maritima; $\mathrm{n}=6$ for chlorophyll aj is presented 
Table 2. Ruppia maritima and green macroalgae. Comparison of biomass values (peak and/or annual means) for shallow coastal sites in New England and the Mid-Atlantic. Different genera of green macroalgae are included, principally Enteromorpha, Cladophora, and Ulva

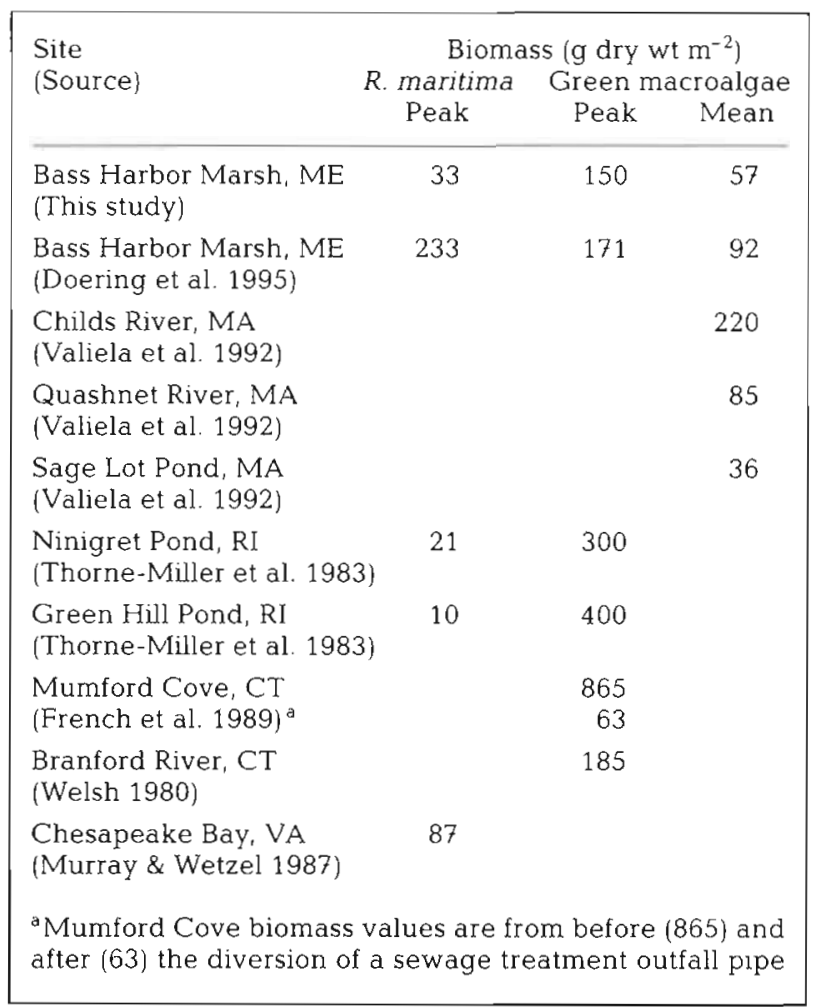

As with Ruppia maritima, green macroalgal biomass in this study is comparable to other New England sites (Table 2) except those with high nutrient loading (Childs River, MA, USA, and Mumford Cove, CT, USA). In addition, peak green macroalgal biomass in the nutrient-enriched Venice Lagoon, Italy (1060 g dry wt $\mathrm{m}^{-2}$; Sfriso et al. 1987), and Peel Inlet, Australia (1250 $\mathrm{g}$ dry wt $\mathrm{m}^{-2}$; Lavery et al. 1991), greatly exceeded levels found in Bass Harbor Marsh.

Mumford Cove provides an interesting example of the effects of reduced nutrient supply. Nutrient inputs from a waste water treatment facility had encouraged a virtual monoculture of Ulva lactuca, covering $74 \%$ of this shallow estuary in 1987 (French et al. 1989, Harlin 1995). Following diversion of the sewage outfall pipe in 1987, U. lactuca areal coverage sharply declined to $3 \%$ with a dramatic drop in biomass (Table 2). The immediate response of $U$. lactuca to nutrient reduction points to the opportunistic and potentially ephemeral behavior of green macroalgae species. Studies in Waquoit Bay showed that Cladophora vagabunda growing in a more nutrient-enriched environment (Childs River) actually had higher nitrogen uptake and photosynthetic rates than $C$. vagabunda from a less enriched site, indicating a physiological adaption to higher nutrient concentrations (Valiela et al. 1992). Because of this opportunistic behavior, green macroalgae can colonize areas receiving excess nutrients and outcompete other primary producers in the system. When Harlin \& Thorne-Miller (1981) fertilized seagrass beds in Ninigret Pond (RI), green macroalgal growth dominated the response. Nitrate additions enhanced the growth of U. lactuca and Enteromorpha spp. but not Ruppia maritima. When ammonium was added, $R$. maritima biomass actually declined while $U$. lactuca and Enteromorpha spp. biomass increased. These manipulative field experiments further support the hypothesis that green macroalgae species are the competitive dominants in shallow nitrogen-enriched coastal systems

\section{Phytoplankton biomass}

Phytoplankton biomass measured as chlorophyll a exhibited a different seasonal trend than the macrophytes (Fig. 2). Chlorophyll levels were very low $\left(<1 \mu \mathrm{g} \mathrm{l}^{-1}\right)$ until late July when they peaked at $11 \mu \mathrm{g} \mathrm{I}^{-1}$ and then remained relatively high ( 4 to $5 \mathrm{\mu g} \mathrm{l}^{-1}$ ) until late November. The sharp increase in chlorophyll a coincided with the decrease in macroalgal biomass, suggesting a competitive dynamic between macroalgae and phytoplankton. This inverse relationship may be a result of macroalgae outcompeting phytoplankton for nutrients. Nutrients remineralized during macroalgal decay may have triggered the phytoplankton bloom. Similarly in the highly eutrophied Venice Lagoon, successive peaks of chlorophyll a (>100 $\left.\mathrm{g} \mathrm{g}^{-1}\right)$ coincided with high water column nutrient concentrations resulting from decomposing UIva rigida (Sfriso et al. 1987).

The competitive dominance of macroalgae reported in field studies has also been documented in enclosure experiments. Fong et al. (1993) found that with high levels of nitrate loading, algal mats outcompeted phytoplankton, as evidenced by a 10 -fold reduction in chlorophyll a. Similarly, Oviatt (1994) reported that macroalgae outcompeted phytoplankton in nitrogen-enriched mesocosms. In other enclosure experiments, the results have been quite different. A study conducted in mesocosms, designed to simulate Rhode Island coastal lagoons, produced a phytoplanton-dominated response to nutrient enrichment (Taylor et al. 1995). A sharp increase in phytoplankton biomass (up to $160 \mathrm{\mu g} \mathrm{l}^{-1}$ ) in nitrogen and phosphorus addition tanks reduced light to below the light saturation levels for eelgrass and Cladophora sp. Competition for light became a key factor in the decline of both eelgrass and macroalgae under nutrient-enriched conditions. 
In Bass Harbor Marsh, peak chlorophyll a levels of $11 \mathrm{Hg} \mathrm{l}^{-1}$ were well below levels reported in the Rhode Island nutrient addition tanks. Though phytoplankton biomass in the marsh peaked when macroalgal biomass declined, levels still remained fairly low throughout the entire growth season (Fig. 2). When compared with the Waquoit Bay sites (Valiela et al. 1992), mean chlorophyll a levels in Bass Harbor Marsh (2.6 $\mathrm{mg} \mathrm{m}^{-3}$ ) were similar to the mean concentrations found in Quashnet River, MA $15.9 \mathrm{mg}$ $\mathrm{m}^{-3}$ ) and Sage Lot Pond, MA (3.9 $\mathrm{mg} \mathrm{m}^{-3}$ ) and lower than those in Childs River $\left(25.5 \mathrm{mg} \mathrm{m}^{-3}\right)$, the most nutrient-enriched site. While competition with macroalgae for either nutrients or light may be the controlling factor in Bass Harbor Marsh, flushing rate may also be maintaining a low phytoplankton biomass. In the mesocosm experiment (Taylor et al. 1995), residence time was on the order of $3 \mathrm{wk}$, while in Bass Harbor Marsh, residence time is much shorter-less than $3 \mathrm{~d}$. In the marsh, phytoplankton may be flushed from the system before bloom conditions can develop.

\section{Primary productivity}

Instantaneous production and respiration rates varied over the growing season for all 3 primary producers (Table 3). Only Ruppia maritima exhibited a distinct seasonal cycle with consistently higher net productivity during the summer months. Over the growing season, $R$. maritima net production ranged from near zero in late April to a maximum of $3.7 \mathrm{mg} \mathrm{C} \mathrm{g}^{-1}$ dry $w t \mathrm{~h}^{-1}$ in

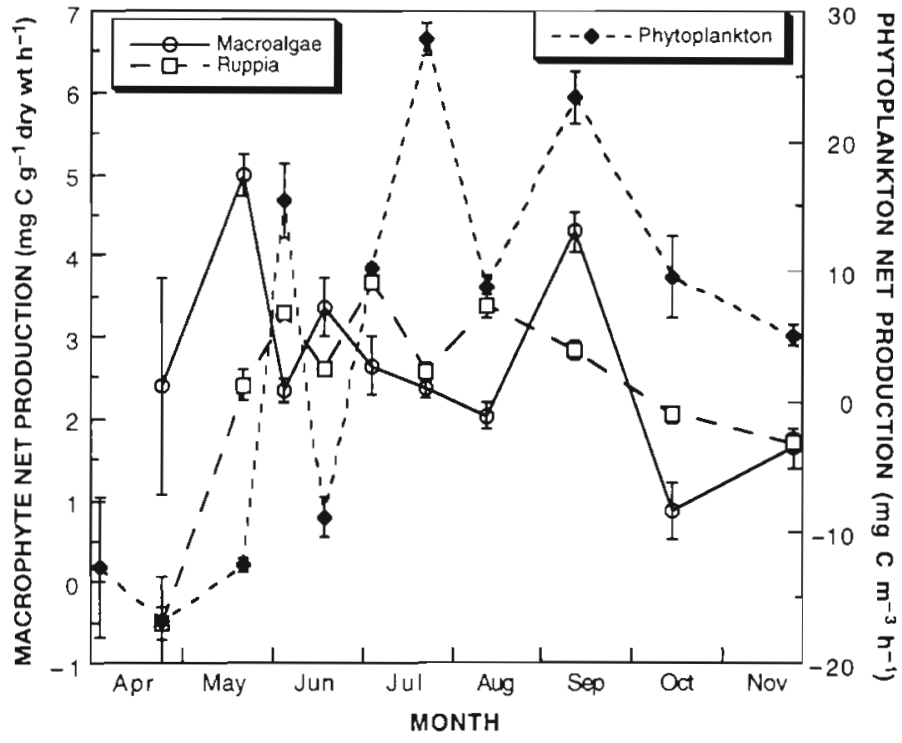

Fig. 3. Macroalgae, Ruppia maritima and phytoplankton. In situ net production rates expressed in carbon, over the growing season. Mean \pm standard error $(n=3)$ is presented

early July (Fig, 3). Because $R$. maritima was incubated without macroalgae, these net production rates likely represent maximum values due to lack of shading. Temperature, which ranged from 6.0 to $25.5^{\circ} \mathrm{C}$, explained over $60 \%$ of the seasonal variability in $R$. maritima's net production $\left(\mathrm{R}^{2}=0.63, \mathrm{p}<0.0001\right)$, while temperature and ammonium concentrations combined accounted for over $80 \%$ of the variability ( $y=0.66 x_{1}+$ $\left.2.88 \mathrm{x}_{2}-5.76, \mathrm{R}^{2}=0.84, \mathrm{p}<0.0001\right)$. The Bass Harbor Marsh net production rates measured for $R$. maritima were similar to the maximum photosynthetic rates

Table 3. Macroalgae, Ruppia maritima and phytoplankton. Net production and respiration in Bass Harbor Marsh. Standard error is included in parentheses $(n=3)$. Negative net production values indicate net $\mathrm{O}_{2}$ respiration in the light chambers. Zeros indicate no measurable respiration in the dark chambers. ND: no data. On April 4, macroalgae and $R$. maritima had not yet appeared in the marsh

\begin{tabular}{|c|c|c|c|c|c|c|}
\hline \multirow{2}{*}{ Date } & \multicolumn{3}{|c|}{ Net production } & \multicolumn{3}{|c|}{ Respiration } \\
\hline & $\begin{array}{c}\text { Macroalgae } \\
\left(\mathrm{mg} \mathrm{O}_{2} \mathrm{~g}^{-1} \text { dry wt h } \mathrm{h}^{-1}\right)\end{array}$ & $\begin{array}{c}\text { R. maritima } \\
\left(\mathrm{mg} \mathrm{O}_{2} \mathrm{~g}^{-1} \mathrm{dry} w t \mathrm{~h}^{-1}\right)\end{array}$ & $\begin{array}{l}\text { Phytoplankton } \\
\left(\mathrm{g} \mathrm{O}_{2} \mathrm{~m}^{-3} \mathrm{~h}^{-1}\right)\end{array}$ & $\begin{array}{c}\text { Macroalgae } \\
\left(\mathrm{mg} \mathrm{O}_{2} \mathrm{~g}^{-1} \text { dry wt } \mathrm{h}^{-1}\right)\end{array}$ & $\begin{array}{c}\text { R. maritima } \\
\left(m g \mathrm{O}_{2} \mathrm{~g}^{-1} \text { dry wt } \mathrm{h}^{-1}\right)\end{array}$ & $\begin{array}{l}\text { Phytoplankton } \\
\left(\mathrm{g} \mathrm{O}_{2} \mathrm{~m}^{-3} \mathrm{~h}^{-1}\right)\end{array}$ \\
\hline Apr 4 & ND & ND & $-0.040(0.017)$ & ND & ND & 0.036 \\
\hline Apr 25 & $7.69(4.22)$ & $-1.70(0.70)$ & $-0.054(0.011)$ & $2.14(0.69)$ & $3.65(0.49)$ & $0.058(0.006)$ \\
\hline May 25 & $16.00(0.84)$ & $8.03(0.61)$ & $-0.040^{\prime}(0.002)$ & $0.99(0.06)$ & $4.27(0.46)$ & $0.046(0.003)$ \\
\hline Jun 6 & $7.50(0.49)$ & $10.92(0.17)$ & $0.049(0.009)$ & $2.27(0.07)$ & $1.84(0.25)$ & 0 \\
\hline Jun 20 & $10.75(1.17)$ & $8.69(0.13)$ & $-0.028(0.005)$ & $1.66(0.14)$ & $2.93(0.08)$ & $0.025(0.002)$ \\
\hline Jul 6 & $8.44(1.14)$ & $12.16(0.13)$ & $0.033(0.001)$ & $3.75(0.06)$ & $2.76(0.08)$ & 0 \\
\hline Jul 25 & $7.61(0.40)$ & $8.56(0.40)$ & $0.089(0.004)$ & $1.34(0.04)$ & $1.76(0.11)$ & 0 \\
\hline Aug 15 & $6.48(0.50)$ & $11.23(0.46)$ & $0.028(0.003)$ & $2.63(0.35)$ & $1.40(0.21)$ & 0 \\
\hline Sep 14 & $13.74(0.78)$ & $9.45(0.40)$ & $0.075(0.006)$ & $2.86(0.04)$ & $0.84(0.18)$ & 0 \\
\hline Oct 18 & $2.82(1.11)$ & $6.81(0.31)$ & $0.031(0.010)$ & $3.33(0.23)$ & $2.62(0.44)$ & $0.013(0.001)$ \\
\hline Nov 28 & $5.25(0.77)$ & $5.71(0.32)$ & $0.016(0.003)$ & $0.85(0.09)$ & 0 & 0 \\
\hline
\end{tabular}


( $P_{\text {max }}: 0.96$ to $3.85 \mathrm{mg} \mathrm{C} \mathrm{g}^{-1}$ dry wt $\mathrm{h}^{-1}$ ) calculated for $R$. maritima in Chesapeake Bay over a temperature range of 1 to $28^{\circ} \mathrm{C}$ (Wetzel \& Penhale 1983). In that study, $R$. maritima production also correlated with temperature.

Macroaigal net production rates were more variable over the growth season and not easily explained by the measured parameters (light, temperature, salinity, \% tissue $\mathrm{N}$, nitrate, nitrite, ammonium, and phosphate). Rates ranged from 0.88 to $5.00 \mathrm{mg} \mathrm{C} \mathrm{g}^{-1}$ dry wt $\mathrm{h}^{-1}$ (Fig. 3). The maximum rate was measured at an ambient water temperature of $21.5^{\circ} \mathrm{C}$ and is lower than the peak net photosynthetic rate $\left(7.3 \mathrm{mg} \mathrm{C} \mathrm{g}^{-1}\right.$ dry wt $\mathrm{h}^{-1}$ at $21^{\circ} \mathrm{C}$ ) determined for Enteromorpha intestinalis in laboratory experiments (Arnold \& Murray 1980). The only measured parameter which explained, albeit weakly, some of the variability in macroalgal net production was percent tissue nitrogen $\left(y=-1.68 x_{1}+\right.$ $\left.12.03, \mathrm{R}^{2}=0.23, \mathrm{p}=0.004\right)$. The negative regression coefficient indicates that higher rates of production were measured at times of lower tissue nitrogen content. This may be due to the greater utilization of stored nitrogen at times of higher production. Several studies with green macroalgae have found low tissue nitrogen during summer, suggesting that higher growth depleted internal nitrogen stores (Hanisak 1979, Birch et al. 1981).

Aside from late April when Ruppia maritima net production was near zero, both $R$. maritima and macroalgae had measurable net daytime production throughout the growth season. Phytoplankton showed no measurable net daytime production in April, May or late June (Table 3). At other times, net production rates varied from 0.016 to $0.089 \mathrm{~g} \mathrm{O}_{2} \mathrm{~m}^{-3} \mathrm{~h}^{-1}$ (5.0 to $27.8 \mathrm{mg}$ $\mathrm{C} \mathrm{m}^{-3} \mathrm{~h}^{-3}$; Fig. 3). As with chlorophyll, these rates are comparable to phytoplankton production measured in Waquoit Bay's Sage Lot Pond (10 to $50 \mathrm{mg} \mathrm{C} \mathrm{m}^{-3} \mathrm{~h}^{-1}$ ), but not to rates found in the more nutrient-enriched Childs River (100 to $200 \mathrm{mg} \mathrm{C} \mathrm{m}{ }^{-3} \mathrm{~h}^{-1}$; Valiela et al. 1992). In Bass Harbor Marsh, maximum phytoplankton net production occurred in late July, when chlorophyll a peaked in the system (Fig. 2). The relationship between phytoplankton net production and chlorophyll a was significant over the course of the study $\left(\mathrm{R}^{2}=0.45, \mathrm{p}<0.0001\right)$. As described earlier, chlorophyll a concentrations in Bass Harbor Marsh were low (mean $=2.6 \mu \mathrm{g} \mathrm{l}^{-1}$ ). It is not surprising that net phytoplankton production was also low or at times zero in the marsh because of competition with macroalgae and a high flushing rate.

Conversion of net production rates to an areal basis allows for comparison between the different primary producers and their relative contribution to system productivity. Macroalgal net production clearly dominated, with peak summer rates exceeding $400 \mathrm{mg} \mathrm{C}$ $\mathrm{m}^{-2} \mathrm{~h}^{-1}$ (Fig. 4). Ruppia maritima peak net production

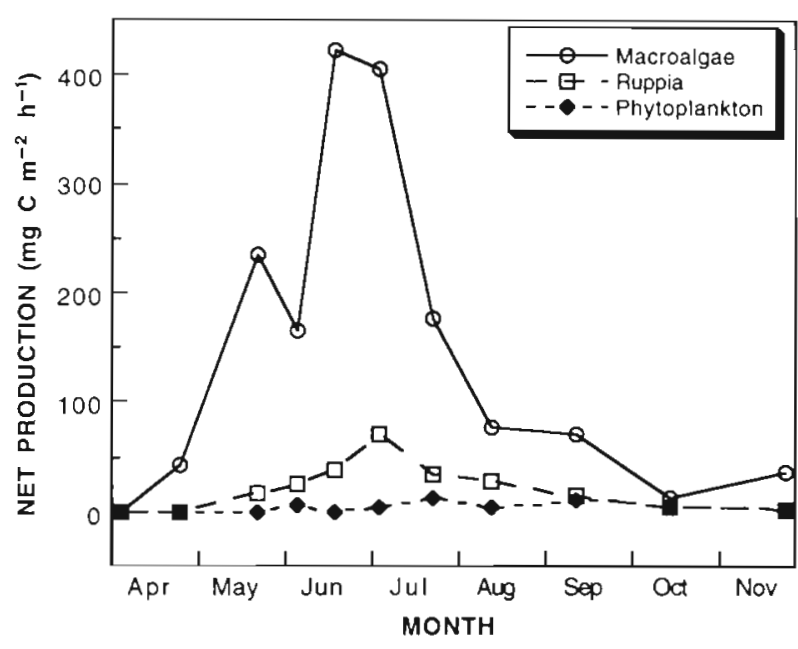

Fig. 4. Macroalgae, Ruppia maritima and phytoplankton. Net production calculated on an areal (per $\mathrm{m}^{2}$ ) basis over the growing season

was $70 \mathrm{mg} \mathrm{C} \mathrm{m} \mathrm{m}^{-2} \mathrm{~h}^{-1}$, while phytoplankton's was only $12 \mathrm{mg} \mathrm{C} \mathrm{m}^{-2} \mathrm{~h}^{-1}$. When converted from a $\mathrm{m}^{2}$ to a system-wide basis for the 20 ha lower basin, macroalgal net production (0 to $61 \mathrm{~kg} \mathrm{C}$ system ${ }^{-1} \mathrm{~h}^{-1}$ ) still dominated that of $R$. maritima (0 to $3.9 \mathrm{~kg} \mathrm{C}$ system $^{-1} \mathrm{~h}^{-1}$ ) and phytoplankton (0 to $2.7 \mathrm{~kg} \mathrm{C}$ system ${ }^{-1} \mathrm{~h}^{-1}$ ).

Macroalgal annual net daylight production was $305 \mathrm{~g} \mathrm{C} \mathrm{m}^{-2} \mathrm{yr}^{-1}$, greatly exceeding annual rates for both Ruppia maritima ( $46 \mathrm{~g} \mathrm{C} \mathrm{m}^{-2} \mathrm{yr}^{-1}$ ) and phytoplankton $\left(11 \mathrm{~g} \mathrm{C} \mathrm{m}^{-2} \mathrm{yr}^{-1}\right)$. Macroalgal production represented $84 \%$ of the total net production of the water column autotrophs, with $R$. maritima contributing $13 \%$ and phytoplankton only $3 \%$. In Waquoit Bay, annual macroalgal production varied by a factor of 2.5 between Sage Lot Pond (443 $\mathrm{g} \mathrm{C} \mathrm{m}^{-2}$ ) and the nutrientenriched Childs River (1094 $\mathrm{g} \mathrm{C} \mathrm{m}^{-2}$; Peckol \& Rivers 1996). Annual net production in Bass Harbor Marsh was similar to that in Sage Lot Pond. However, in Sage Lot Pond (Valiela et al. 1992), the seagrass Zostera marina appeared to be a co-dominant while in Bass Harbor Marsh, macroalgae clearly dominated primary production.

In the Rhode Island salt ponds, shallow macrophytebased communities similar to Bass Harbor Marsh, annual production rates were comparable, though the relative contributions of the plant communities differed. Annual primary production averaged $300 \mathrm{~g} \mathrm{C}$ $\mathrm{m}^{-2} \mathrm{yr}^{-1}$, with seagrasses contributing over $50 \%$, macroalgae and benthic microalgae $40 \%$, and phytoplankton only $10 \%$ (Thorne-Miller et al. 1983, Lee \& Olsen 1985). The salt ponds did not exhibit the macroalgal dominance evident in Bass Harbor Marsh and in areas such as Childs River, Waquoit Bay. Instead, seagrasses were the dominant autotrophs in the system. However, as indicated by the nutrient-enrichment experiment 
conducted by Harlin \& Thorne-Miller (1981), increases in nutrient loading could change the dominance patterns in salt pond communities by encouraging the proliferation of green macroalgae.

\section{Competitive interactions}

While low phytoplankton production is typical of a number of shallow coastal systems (Lee \& Olsen 1985, Murray \& Wetzel 1987, Valiela et al. 1992, Bass Harbor Marsh, this study) the relatively low Ruppia maritima production in Bass Harbor Marsh is more intriguing. What is driving macroalgal dominance over $R$. maritima in the lower basin of Bass Harbor Marsh? Because light and nutrients are both critical to photosynthesis, an examination of how these resources are partitioned provides insight into the competitive dynamics of water column production in the estuary.

Patterns in tissue nitrogen content differed between macroalgae and Ruppia maritima (Fig. 5). Over the course of the season, macroalgal \% varied from 0.5 to $4.1 \%$ while $R$. maritima \% $\mathrm{N}$ was more constant, ranging from 2.8 to $4.9 \%$. The critical level for tissue nitrogen, defined as the point where growth becomes limited, is $2.0 \%$ for macroalgae (Hanisak 1979, O'Brien \& Wheeler 1987), while $R$. maritima's critical \% $\mathrm{N}$ is 2.5 to $3.0 \%$ (Thursby $1984 \mathrm{~b}$ ). For much of the summer, macroalgal growth was nitrogen limited, with \% tissue $\mathrm{N}$ lower than the critical level (Fig. 5). R. maritima tissue $\mathrm{N}$ was never limiting. Macroalgae can only utilize nutrients dissolved in the water column, as supported by a similar seasonal trend of dissolved inorganic nitrogen and tissue $\mathrm{N}$ (Fig. 5). In contrast, $R$. maritima has access to both nitrogen and phosphorus in the sediments, and the predominance of root-to-shoot nutrient translocation has been demonstrated (Thursby \& Harlin 1984). In the lower basin, phosphate is consistently low $\left(<0.5 \mu \mathrm{mol} \mathrm{l}^{-1}\right)$ in the water column, while dissolved inorganic nitrogen is low during summer and early fall $\left(<2.0 \mu \mathrm{mol} \mathrm{l}^{-1}\right)$. Therefore the sediments must constitute an important nutrient reservoir for $R$. maritima, particularly as it must compete with opportunist green macroalgae, which are capable of rapid nutrient uptake and growth rates (Fong et al. 1994)

Because of Ruppia maritima's higher tissue nitrogen content and access to sediment reservoirs, competition for nutrients is likely not the factor limiting its growth. Instead, light is probably the critical factor. In nutrientenriched natural and experimental systems

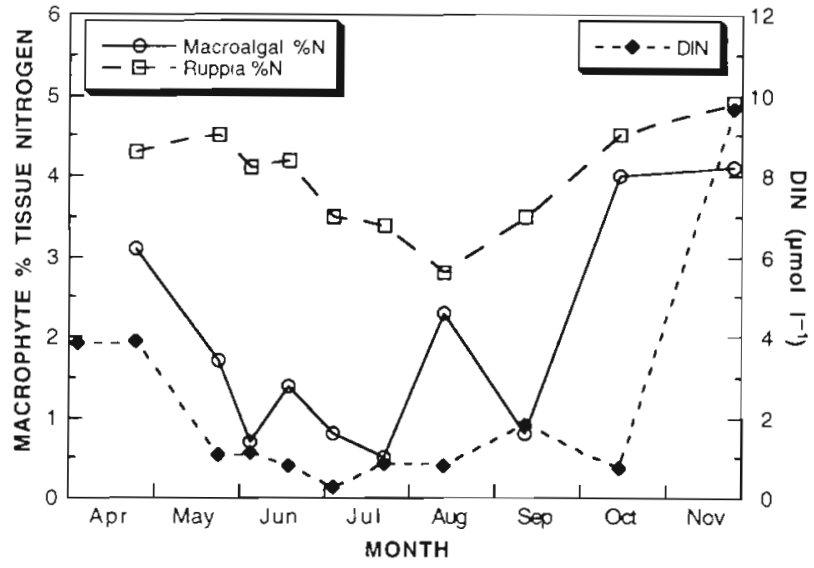

Fig. 5. Macroalgae and Ruppia maritima. Macrophyte percent tissue nitrogen and water column dissolved inorganic nitrogen (DIN) presented over the growth season

where seagrasses have declined, nutrients triggered blooms of either macroalgae (Harlin \& Thorne-Miller 1981, Valiela et al. 1992) or phytoplankton (Twilley et al. 1985, Taylor et al. 1995), with consequent seagrass shading. The photosynthetic saturation intensities for R. maritima are around 250 to $500 \mu \mathrm{E} \mathrm{m}^{-2} \mathrm{~s}^{-1}$ (Wetzel \& Penhale 1983). In Bass Harbor Marsh, light levels at the bottom were generally at or above these intensities in areas free of macroalgae (Table 1). Therefore, water column light attenuation did not appear to limit $R$. mar-

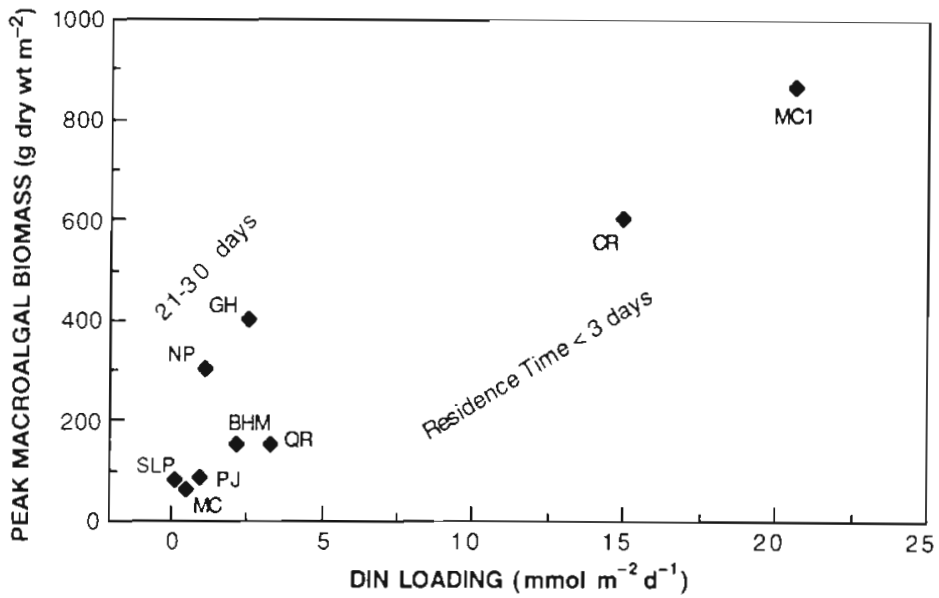

Fig. 6. Relationship between peak green macroalgal biomass and dissolved inorganic nitrogen (DIN) loading for shallow estuarine sites in New England with short and long residence times. BHM: Bass Harbor Marsh (this study). CR: Childs River, MA; QR: Quashnet River, MA; SLP: Sage Lot Pond, MA (D'Avanzo et al. 1996, Hersh 1996). GH: Green Hill Pond, RI; NP: Ninigret Pond, RI; PJ: Pt. Judith Pond, RI (Isaji \& Spaulding 1981, Thorne-Miller et al. 1983, Lee \& Olsen 1985). MC: Mumford Cove, CT, after diversion of sewage outfall pipe; MC1. Mumford Cove, CT, before diversion of sewage outfall pipe (French et al. 1989). DIN loading for MC1 was calculated by multiplying sewagebased total nitrogen loading by 0.85 (Nixon 1992) 
itima survival. However, the dominant macroalgal biomass shades $R$. maritima throughout the growth season. In this way, macroalgae may be outcompeting $R$. maritima for light and thereby dominating primary production in the lower basin.

\section{CONCLUSIONS}

Small shallow systems are often the first to be affected by nutrient enrichment (Valiela et al. 1992). In various sites around New England, there appears to be a relationship between nitrogen loading and green macroalgal biomass in shallow embayments (Fig. 6). Sites with low nitrogen inputs and rapid flushing, such as Bass Harbor Marsh, have low algal biomass relative to estuarine sites with high loading (Childs River, Mumford Cove). The concept that residence time influences the response of estuaries to nutrient loading has been previously discussed (D'Avanzo et al. 1996). Although Ninigret and Green Hill Ponds (RI) have low nitrogen loading rates, high biomass in those sites may be a result of long residence time. Poor tidal flushing may limit the dilution of nutrients brought in by freshwater sources.

Although peak green macroalgal biomass in Bass Harbor Marsh is relatively low, the estuary is displaying productivity patterns characteristic of eutrophied sites. Opportunistic green macroalgae dominated primary production in the lower marsh basin, with net areal production rates far exceeding those of either Ruppia maritima or phytoplankton. Anthropogenic nitrogen may have promoted macroalgal growth, negatively impacting other autotrophs in the lower basin. Thus, Bass Harbor Marsh represents a shallow estuarine system that may be responding to relatively low levels of nutrient enrichment.

Acknowledgements. This study was supported by the National Park Service, Water Resources Division, with funds administered through the Cooperative National Park Studies Unit at the University of Rhode Island (URI). Thanks are extended to Candace Oviatt, Marilyn Harlin and Arthur Gold for their constructive review of earlier drafts of this manuscript. Appreciation is also extended to all those who helped in the field and to the Marine Ecosystem Research Laboratory at URI for the use of lab space and assistance in nutrient analyses.

\section{LITERATURE CITED}

American Public Health Association, American Water Works Association, Water Pollution Control Federation (1980) Standard methods for the examination of water and wastewater, 15th edn. American Public Health Association, Washington, DC

Arnold KE, Murray SN (1980) Relationships between irradiance and photosynthesis for marine benthic green algae
(Chlorophyta) of differing morphologies. J Exp Mar Biol Ecol 43:183-192

Birch PB, Gordon DM, McComb AJ (1981) Nitrogen and phosphorus nutrition of Cladophora in the Peel-Harvey estuarine system, Western Australia. Bot Mar 24:381-387

D'Avanzo C, Kremer JN (1994) Diel oxygen dynamics and anoxic events in an eutrophic estuary of Waquoit Bay, Massachusetts. Estuaries 17:131-139

D'Avanzo C, Kremer JN, Wainright SC (1996) Ecosystem production and respiration in response to eutrophication in shallow temperate estuaries. Mar Ecol Prog Ser 141: $263-274$

Doering PH, Roman CT, Beatty LL, Keller AA, Oviatt CA (1995) Water quality and habitat evaluation of Bass Harbor Marsh, Acadia National Park, Maine. Technical Report NPS/NESORNR/NRTR/95-31. National Park Service, New England System Support Office, Boston, MA

Farris CN (1996) Oxygen exchange and nutrient transformation rates under fluctuating salinity treatments in two subtidal marsh habitats. PhD thesis, University of Rhode Island

Fong P, Donohoe RM, Zedler JB (1993) Competition with macroalgae and benthic cyanobacterial mats limits phytoplankton abundance in experimental microcosms. Mar Ecol Prog Ser 100:97-102

Fong P, Donohoe RM, Zedler JB (1994) Nutrient concentration in tissue of the macroalga Enteromorpha as a function of nutrient history: an experimental evaluation using field microcosms. Mar Ecol Prog Ser 106:273-281

French D, Harlin M, Gundlach E, Pratt $S$, Rines H, Jayko K, Turner C, Puckett S (1989) Mumford Cove water quality: 1988 monitoring study and assessment of historical trends. Final report. ASA Inc, Narragansett, RI

Hanisak MD (1979) Nitrogen limitation of Codium fragile ssp. tomentosoides as determined by tissue analysis. Mar Biol 50:333-337

Harlin MM (1995) Changes in major plant groups following nutrient enrichment. In: McComb AJ (ed) Eutrophic shallow estuaries and lagoons. CRC Press, Boca Raton, FL, p $173-187$

Harlin MM, Thorne-Miller B (1981) Nutrient enrichment of seagrass beds in a Rhode Island coastal lagoon. Mar Biol 65:221-229

Hersh DA (1996) Abundance and distribution of intertidal and subtidal macrophytes in Cape Cod: the role of nutrient supply and other controls. $\mathrm{PhD}$ thesis, Boston University

Howarth RW (1988) Nutrient limitation of net primary production in marine ecosystems. Annu Rev Ecol 19:89-110

Isaji T, Spaulding ML (1981) A simplified model for assessing the impact of breachway modifications on coastal pond circulation and flushing dynamics. In: Proc Oceans ' 81 Institute of Electrical and Electronics Engineers, Inc (IEEE), New York, p 824-828

Johnston CS (1969) The ecological distribution and primary production of macrophytic marine algae in the Eastern Canaries. Int Rev Ges Hydrobiol 54:473-490

Lavery PS, Lukatelich RJ, McComb AJ (1991) Changes in the biomass and species composition of macroalgae in a eutrophic estuary. Estuar Coast Shelf Sci 33:1-22

Lavery PS, McComb AJ (1991) Macroalgal-sediment nutrient interactions and their importance to macroalgal nutrition in a eutrophic estuary. Estuar Coast Shelf Sci 32:281-295

Lee V, Olsen S (1985) Eutrophicaton and management initiatives for the control of nutrient inputs to Rhode Island coastal lagoons. Estuaries 8:191-202

Littler MM (1979) The effects of bottle volume, thallus weight, oxygen saturation levels, and water movement on apparent photosynthetic rates in marine algae. Aquat Bot 7:21-34 
Murray L, Wetzel RL (1987) Oxygen production and consumption associated with the major autotrophic components in two temperate seagrass communities. Mar Ecol Prog Ser 38:231-239

Nixon SW (1992) Quantifying the relationship between nitrogen input and the productivity of marine ecosystems. Proc Adv Mar Tech Conf 5:57-83

Nixon SW (1995) Coastal marine eutrophication: a definition, social causes, and future concerns. Ophelia 41:199-219

O'Brien MC. Wheeler PA (1987) Short term uptake of nutrients by Enteromorpha prolifera (Chlorophyceae). J Phycol 23:547-556

Oviatt C (1994) Biological considerations in marine enclosure experiments: challenges and revelations. Oceanography $7: 45-51$

Oviatt C, Doering P, Nowicki B, Reed L, Cole J, Frithsen J (1995) An ecosystem level experiment on nutrient limitation in temperate coastal marine environments. Mar Ecol Prog Ser 116:171-179

Oviatt CA, Rudnick DT, Keller AA, Sampou PA, Almquist GI (1986) A comparison of system $\left(\mathrm{O}_{2}\right.$ and $\left.\mathrm{CO}_{2}\right)$ and $\mathrm{C}-14$ measurements of metabolism in estuarine mesocosms. Mar Ecol Prog Ser 28:57-67

Peckol P, Rivers JS (1996) Contribution by macroalgal mats to primary production of a shallow embayment under high and low nitrogen-loading rates. Estuar Coast Shelf Sci 43: 311-325

Ryther JH, Dunstan WM (1971) Nitrogen, phosphorus, and eutrophication in the coastal marine environment. Science 171:1008-1013

Sfriso A, Marcomini A, Pavoni B (1987) Relationship between macroalgal biomass and nutrient concentrations in a hypertrophic area of the Venice Lagoon. Mar Environ Res 22:297-312

Strickland JDH, Parsons TR (1972) A practical handbook of seawater analysis. Bull Fish Res Bd Can 167

Taylor DI, Nixon SW, Granger SL, Buckley BA, McMahon JP,

Editorial responsibility: Gordon Thayer (Contributing Editor), Beaufort, North Carolina, USA
Lin HJ (1995) Responses of coastal lagoon plant communities to different forms of nutrient enrichment-a mesocosm experiment. Aquat Bot 52:19-34

Thorne-Miller B, Harlin MM, Thursby GB, Brady-Campbell MM, Dworetzky BA (1983) Variations in the distribution and biomass of submerged macrophytes in five coastal lagoons in Rhode Island, USA. Bot Mar 16:231-242

Thursby GB (1984a) Root exuded oxygen in the aquatic angiosperm Ruppia maritima. Mar Ecol Prog Ser 16:303-305

Thursby GB (1984b) Nutritional requirements of the submerged angiosperm Ruppia maritima in algae-free culture. Mar Ecol Prog Ser 16:45-50

Thursby GB, Harlin MM (1984) Interaction of leaves and roots of Ruppia maritima in the uptake of phosphate, ammonia and nitrate. Mar Biol 83:61-67

Twilley RR, Kemp WM, Staver KW, Stevenson JC, Boynton WR (1985) Nutrient enrichment of estuarine submersed vascular plant communities. 1. Algal growth and effects on production of plants and associated communities. Mar Ecol Prog Ser 23:179-191

Valiela I (1995) Marine ecological processes, 2nd edn. SpringerVerlag, New York

Valiela I, Foreman $\mathrm{K}$, LaMontagne $\mathrm{M}$, Hersh D, Costa J Peckol P, DeMeo-Andreson B, D'Avanzo C, Babione M, Sham C, Brawley J, Lajtha K (1992) Couplings of watersheds and coastal waters: sources and consequences of nutrient enrichment in Waquoit Bay, Massachusetts. Estuaries 15:443-457

Vollenweider RA (1965) Calculation models of photosynthesis-depth curves and some implications regarding day rate estimates in primary production measurements. Mem Ist Ital Idrobiol 18(Suppl):425-457

Welsh BL (1980) Comparative nutrient dynamics of a marshmudflat ecosystem. Estuar Coast Mar Sci 10:143-164

Wetzel RL, Penhale PP (1983) Production ecology of seagrass communities in the lower Chesapeake Bay. Mar Tech Soc J 17:22-31

Submitted: June 10, 1997: Accepted: November 25, 1997 Proofs received from author(s): February 17, 1998 